\title{
EFFECT OF PROTEIN CONCENTRATE SUPPLEMENT ON THE QUALITATIVE AND QUANTITATIVE PARAMETERS OF MILK FROM DAIRY COWS IN ORGANIC FARMING*
}

\author{
Pavel Horký \\ Department of Animal Nutrition and Forage Production, Mendel University in Brno, \\ Zemědělská 1, 61300 Brno, Czech Republic \\ Corresponding author: pavel.horky@mendelu.cz
}

\begin{abstract}
In our experiment, we studied the effects of protein concentrate addition on the qualitative and quantitative composition of milk in organically farmed dairy cows. A total number of $\mathbf{4 0}$ Holstein cows were divided into two groups. Live weight of dairy cows was around $625 \pm 25 \mathrm{~kg}$. Average production efficiency of animals was $\mathbf{7 6 0 0} \pm \mathbf{5 0} \mathrm{kg}$ milk for the lactation period. Animals of both groups received identical basal feed ration. The first experimental group of cows $(n=20)$ received in the feed ration a protein concentrate from organic production (soybean cake $60 \%$, sunflower cake $20 \%$, linseed cake $20 \%$ ) at $1 \mathrm{~kg}$ per head and day. The second group served as a control $(n=20)$ without the addition of protein concentrate. The experiment lasted 30 days. The goal of the experiment was to investigate whether the addition of protein concentrate can affect individual milk components. The measured values show that the experimental group of dairy cows with the addition of protein concentrate exhibited increases in fat content by $7.4 \%(P \leq 0.05)$, in urea content by $83.1 \%(\mathrm{P} \leq 0.001)$ and in citric acid content by $18.6 \%(\mathrm{P} \leq 0.01)$, and decreases in free fatty acids by $54.9 \%(\mathrm{P} \leq 0.001)$, in ECM by $5.5 \%(\mathrm{P} \leq 0.05)$ and in FCM by $6.1 \%(\mathrm{P} \leq 0.05)$. The control group of cows exhibited the citric acid content in milk increased by $20.0 \%(P \leq 0.05)$. The results indicate that the protein concentrate composed of soybean, sunflower and linseed cakes can affect the composition of milk from organically farmed dairy cows.
\end{abstract}

Key words: protein concentrate, milk, cows, organic farming

The importance of organic farming has been recently increasing - Figures $1 \mathrm{~A}$ and $1 \mathrm{~B}$ (Willer and Kilcher, 2009). The trend is also supported by the policy of the European Union largely promoting organic farming (Lelyon et al., 2012). Protein supplements represent an indispendable component of feed rations for high-yielding dairy cows. However, feeding of ruminants with animal proteins and fishmeal was

*This work has been implemented in the context of grant TP $3 / 2013$ financed by the Internal Grant Agency (IGA) of Faculty of Agronomy, Mendel University in Brno, Czech Republic. Preparation and implementation of this article is supported also by resources of the project CZ.1.07/2.3.00/20.005 "The excellence of Ph.D. studies at FA MENDELU for the following scientific European career". 
banned in the European Union (Commission Decision 2001/25/EC) due to spreading the BSE (bovine spongiform encephalopathy) disease in beef cattle. Protein sources coming into consideration in the Czech Republic (and the EU) are soybean, oilseed rape, sunflower, legumes and possibly some products of oil industry - extracted meals (Homolka and Kudrna, 2006). With the growing efficiency of the production of dairy cows, which has been lately recorded, the nutrition and feeding of animals become ever more demanding. This primarily concerns the first stage of lactation when the need of basic nutrients (energy and N-substances) can be covered by common feeds only with difficulties (Tetens et al., 2013). Protein concentrate can affect milk components by which the farm economy can be improved (Danes et al., 2013). The use of protein concentrates (based on soybean) in organically farmed dairy cows can increase the content of individual components by up to $10 \%$ (Hoshide et al., 2011). The objective of this experiment was to verify whether a protein concentrate can increase the contents of individual milk components in organically farmed dairy cows.
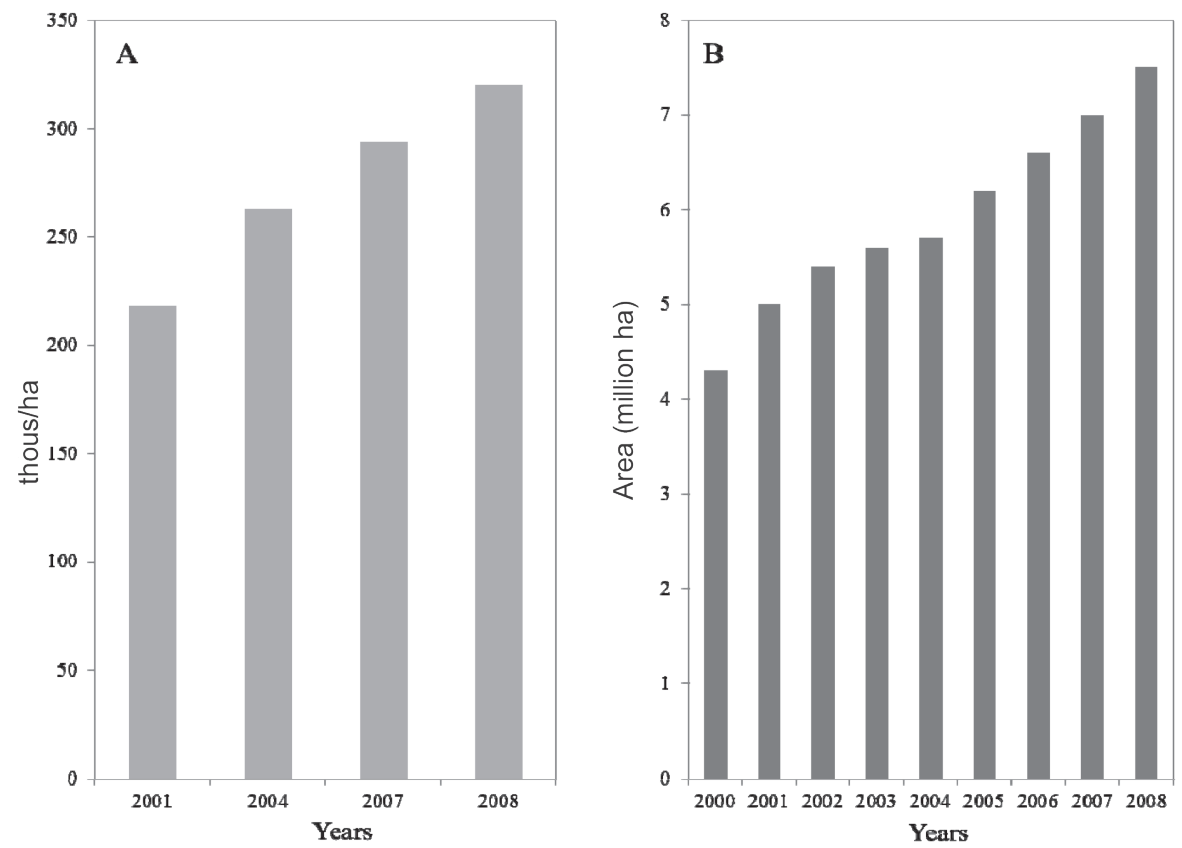

Figure 1. Organic area in the Czech Republic in 2001, 2004, 2007 and 2008 ('000 ha) - (A); Evolution of the area involved in the organic sector in the EU-25 (million ha) - (B) - (Anonymous, 2010)

\section{Material and methods}

The experiment was conducted on the organic farm of dairy cattle in Lesoňovice (Czech Republic) and included 40 Holstein dairy cows divided into two equal groups at the same stage of lactation. The experimental cows were in the third and fourth 
lactation. Live weight of dairy cows was around $625 \pm 25 \mathrm{~kg}$. Average production efficiency of animals was $7600 \pm 50 \mathrm{~kg}$ milk for the lactation period. All animals were fed a basic feed ration in the form of TMR (Table 1) and had ad libitum access to water. The basic composition of nutrients in the respective feeds is presented in Table 3. The first group of dairy cows had the basal feed ration supplemented with a protein concentrate (Table 2 ) at $1 \mathrm{~kg}$ per head and day.

Table 1. Composition of the feed ration for dairy cows

\begin{tabular}{l|c|c}
\hline \multicolumn{1}{c}{ Fodder } & Amount $(\mathrm{kg})$ & Dry matter $(\mathrm{kg})$ \\
\hline Maize silage & 22.00 & 6.38 \\
Clover-grass haylage - first cut & 17.00 & 5.95 \\
Grass haylage - first cut & 10.00 & 4.00 \\
Winter wheat & 3.00 & 2.64 \\
Spring barley & 2.00 & 1.76 \\
Protein concentrate* & 1.00 & 0.88 \\
Detamin GA Spezial & 0.15 & 0.13 \\
\hline
\end{tabular}

Detamin GA Spezial - mineral supplement for ruminants in organic farming (Germany).

*Protein concentrate was not fed to the control group of dairy cows.

Table 2. Composition of the protein concentrate

\begin{tabular}{l|c}
\hline \multicolumn{1}{c|}{ Component } & Amount $(\%)$ \\
\hline Soybean cake* & 60.00 \\
Sunflower cake* & 20.00 \\
Linseed cake* & 20.00 \\
\hline
\end{tabular}

* Raw materials originating from organic farming.

Concentration of crude protein $=36.60 \%$.

Concentration of fat $=10.00 \%$.

Table 3. Nutrient contents in the respective feeds $-100 \%$ dry matter (Zeman et al., 1995)

\begin{tabular}{l|c|c|c|c}
\hline \multicolumn{1}{c|}{ Fodder } & $\begin{array}{c}\text { Crude protein } \\
(\mathrm{g})\end{array}$ & $\begin{array}{c}\text { PDIN } \\
(\mathrm{g})\end{array}$ & $\begin{array}{c}\text { PDIE } \\
(\mathrm{g})\end{array}$ & $\begin{array}{c}\text { NEL } \\
(\mathrm{MJ})\end{array}$ \\
\hline Maize silage & 93.6 & 42.4 & 63.0 & 6.9 \\
Clover-grass haylage - first cut & 171.0 & 98.2 & 72.1 & 5.3 \\
Grass haylage - first cut & 125.7 & 19.2 & 71.5 & 6.3 \\
Winter wheat & 130.0 & 88.7 & 111.2 & 9.0 \\
Spring barley & 135.0 & 88.9 & 104.6 & 8.2 \\
Soybean cake & 479.1 & 336.0 & 209.5 & 8.4 \\
Sunflower cake & 358.0 & 231.3 & 110.9 & 5.8 \\
Linseed cake & 373.2 & 257.6 & 174.9 & 7.5 \\
\hline
\end{tabular}

PDIN $=$ PDIA + PDIMN; PDIE $=$ PDIA + PDIME.

PDIA - non-degraded fodder protein actually digestible in the small intestine.

PDIMN - amount of microbial protein, which can be synthesized in the rumen from the degraded fodder protein if the content of available energy and other nutrients is not limiting.

PDIME - amount of microbial protein, which can be synthesized in the rumen from available energy of the content if degraded fodder protein and other nutrients is not limiting (Zeman et al., 2006). 
The protein concentrate was mixed of raw materials originating from organic farming. The second group of dairy cows served as a control and did not receive any additional protein concentrate in the feed ration. Values of nutrients contained in the feed ration for the two groups are presented in Table 4. The experiment started with the experimental group of dairy cows on day 52 of lactation on average (stage of lactation ranged from 41 to 65 days). The average lactation period in the control group of cows at the beginning of the experiment was 56 days (stage of lactation ranged from 38 to 60 days). The cows were kept in loose housing. They were fed twice a day (morning and evening). The experimental period was set to 30 days. Milk samples were taken before the experiment and at its end (after 30 days). The milk samples were collected before the early feeding and then analysed.

Table 4. Total intake of nutrients in the feed ration

\begin{tabular}{lcc}
\hline \multicolumn{1}{c}{ Fodder component } & Experimental group & Control group \\
\hline Starch $(\mathrm{g})$ & 3758.0 & 3721.0 \\
Crude protein $(\mathrm{g})$ & 3313.0 & 2947.0 \\
Fat $(\mathrm{g})$ & 613.0 & 513.0 \\
PDIN (g) & 2037.0 & 1764.0 \\
PDIE (g) & 1972.0 & 1838.0 \\
NEL (MJ) & 173.2 & 135.5 \\
ADF (g) & 6146.0 & 5948.0 \\
NDF $(\mathrm{g})$ & 9467.0 & 9185.0 \\
\hline
\end{tabular}

The values of nutrients were acquired by calculation according to tabular values.

Crude protein $-\mathrm{N} * 6.25$.

\section{Assessment of milk components}

The milk was conserved by 2-bromo-2-nitropropane-1,3-diol and cooled to $4-6^{\circ} \mathrm{C}$ until analysed. The analysis was carried out within hours from the sampling. Milk components were analysed in a commercial laboratory on the MilkoScan FT 2 instrument (Foss Electric, Hillerod, Denmark). Fat was established acidobutyrometrically according to CSN ISO 2446. Crude protein was established by the Kjeldahl method according to CSN 570530 and lactose was ascertained on the commercial Lactose/D-Galactose Assay Kit MEGAZYME according to IDF 79B:1991. Urea in milk was determined enzymatically on the commercial Urea/Ammonia Assay Kit Megazyme. Free fatty acids were established by extraction-titration method according to CSN 57 0533. Somatic cells and citric acid were analysed by means of FTIR (Fourier Transform InfraRed) technology (MilkoScan, FT 6000) according to CSN EN ISO 13366-2.

\section{Statistics}

The data were processed using Microsoft Excel ${ }^{\circledR}$ and Statistica.Cz Version 10.0 (Czech Republic). Results are expressed as a least squares means \pm standard deviation (SD) $\left(\right.$ Excel $\left.^{\circledR}\right)$. Values of statistical significance of differences among milk production, fat, protein, lactose, somatic cells, free fatty acids, urea and citric acid were ascertained using Statistica.Cz. This model was employed due to irregular calving of 
the cows. Differences with $\mathrm{P} \leq 0.05$ were considered significant and were determined by Student's paired t-test, which was applied for the comparison of means. These values were detected in the respective monitored milk components based on differences between the first and the second milk sampling. Statistical model:

$$
Y=\text { groups }+ \text { day of lactation }+\varepsilon
$$

\section{Results}

No health problems were observed in the experimental animals during the trial. Milk production, which ranged from 22.9 to 28.4 1/day (Figure $2 \mathrm{~A}$ ), did not show significant differences in any of the groups of dairy cows. In assessing milk fat, we found a significant increase by $7.4 \%(\mathrm{P} \leq 0.05)$ in the control group of animals as compared with the first sampling. The control group of cows exhibited a higher amount of milk fat, too (by $2.9 \%$ ), but without statistical significance (Figure 2 B). The content of milk fat ranged from 3.7 to $5.9 \%$. The content of milk proteins was practically at the same level in the experimental and control groups of dairy cows as it was before launching the experimental observation. The values of milk proteins ranged from 3.2 to $4.3 \%$ (Figure $2 \mathrm{C}$ ). The content of lactose did not show any significant changes in the two groups of animals (Figure $2 \mathrm{D}$ ) and ranged from 4.2 to $5.2 \%$.
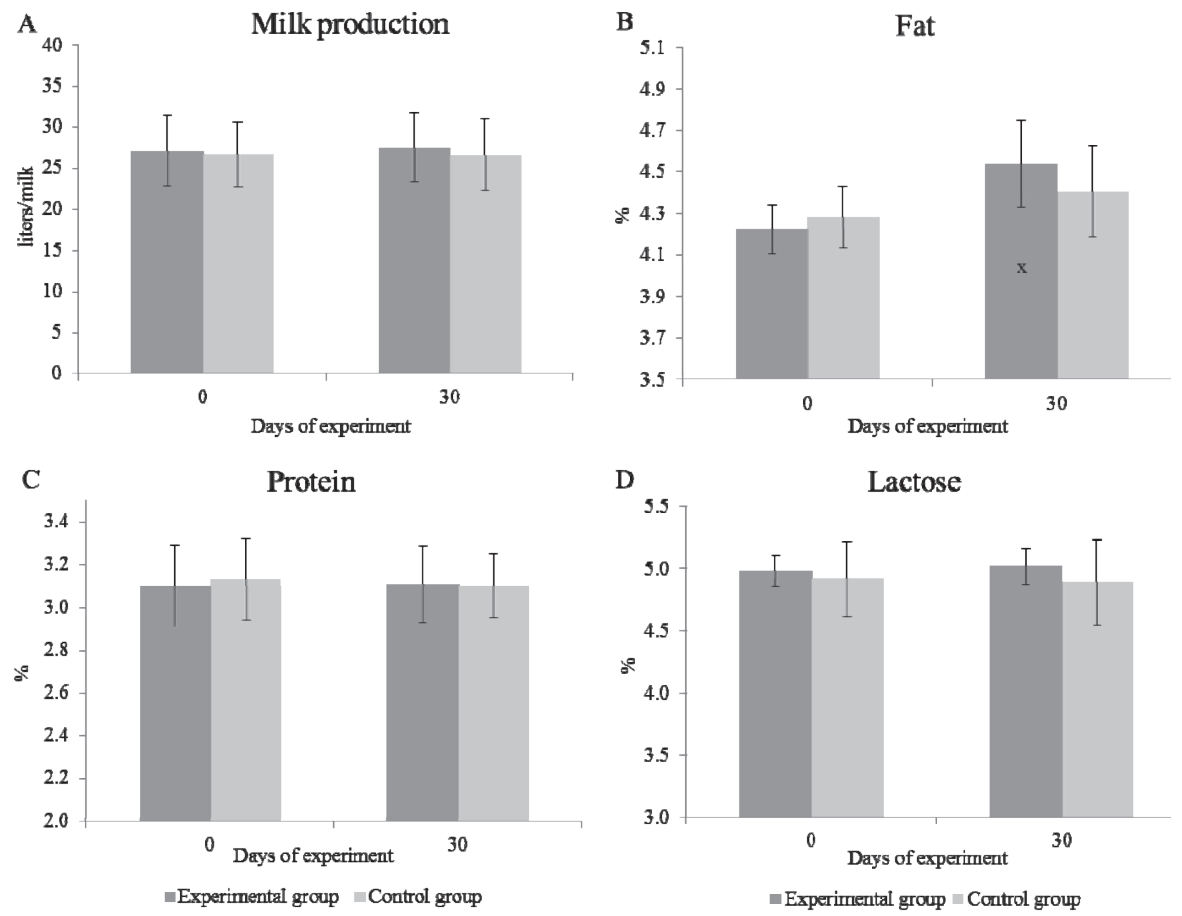

Figure 2. The effect of protein concentrate supplement on the production of milk (A), fat content (B), protein content (C) and lactose content (D). $\mathrm{x}=$ statistical significance $\mathrm{P} \leq 0.05$ between day 0 and day 30 of the experiment 
As compared with the first sampling, somatic cells slightly increased in the experimental and control groups by $10.6 \%$ and $12.0 \%$, respectively. This increase of somatic cells was, however, statistically non-significant (Figure $3 \mathrm{~A}$ ) and ranged from 40.0 to 629.0 thousand $/ \mathrm{ml}$. As to free fatty acids, the experimental group of animals with the protein concentrate added in the feed ration showed a decrease by $54.9 \%(\mathrm{P} \leq 0.001)$. A similar decrease was recorded also in the control group (by $26.8 \%$ ) but was statistically non-significant (Figure $3 \mathrm{~B}$ ). The values of free fatty acids ranged from 0.25 to $1.63 \mathrm{mmol} / 100 \mathrm{~g}$ of fat. Urea increased in the experimental group of cows by $83.1 \%(\mathrm{P} \leq 0.001)$ as compared with the control sampling at the beginning of the trial. Compared with the control milk sampling, the control group of dairy cows exhibited a higher content of urea in milk (by 7.1\%), too, which was, however, statistically non-significant (Figure $3 \mathrm{C}$ ). The concentrations of urea ranged from 16.7 to $36.4 \mathrm{mg} / 100 \mathrm{ml}$. Citric acid increased during the experimental period by $18.6 \%(\mathrm{P} \leq 0.01)$ and the same pattern was recorded in the control group, in which the concentration of citric acid in milk increased by $20.0 \%(\mathrm{P} \leq 0.05)$. The concentrations of citric acid ranged from 0.1 to $0.22 \mathrm{mmol} / 1$ (Figure $3 \mathrm{D}$ ). The assessment of ECM (energy corrected milk) showed an increase by $5.5 \%(\mathrm{P} \leq 0.05)$ in the experimental group of dairy cows. The FCM (fat corrected milk) evaluation revealed a similar significant increase by $6.1 \%(\mathrm{P} \leq 0.05)$ in the experimental group of cows (Table 5).
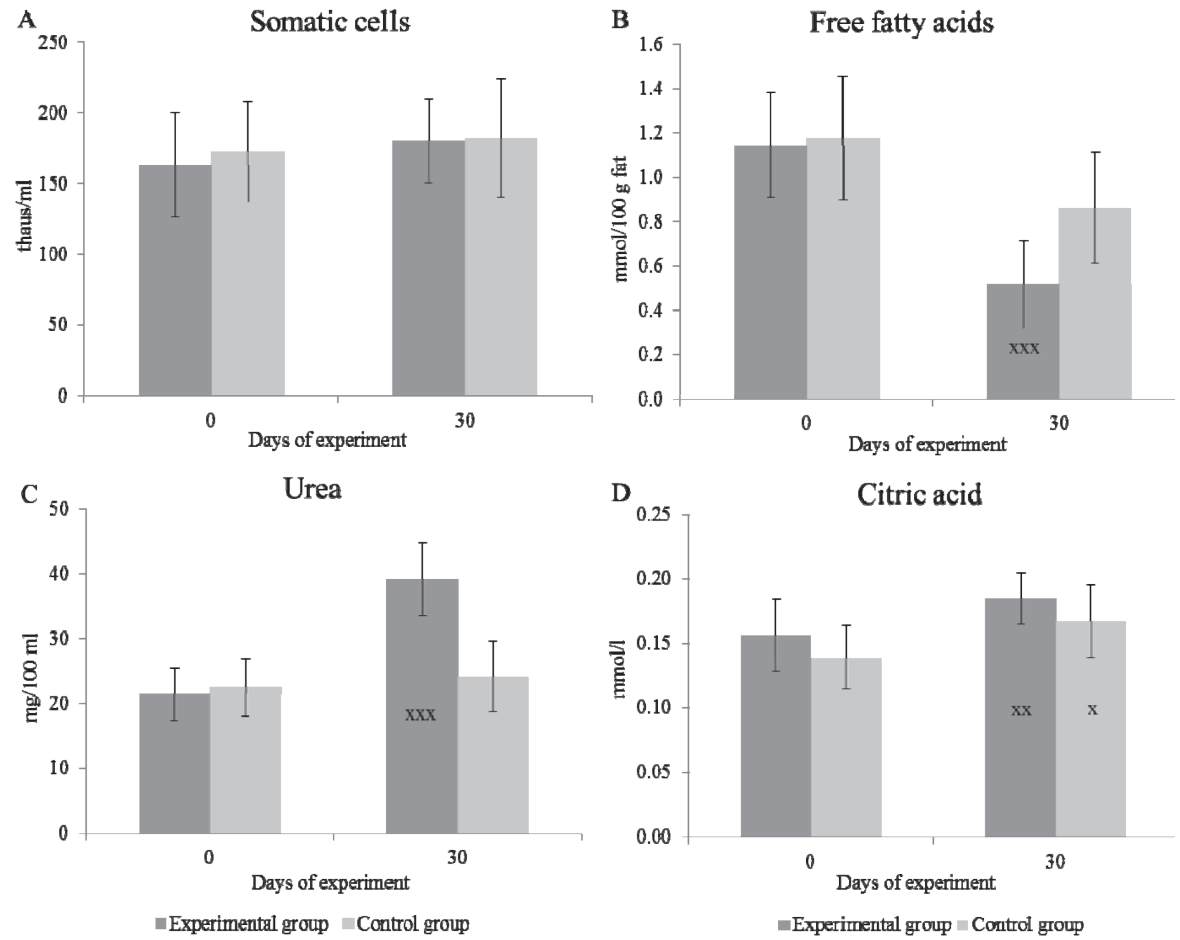

Figure 3. The effect of protein concentrate supplement on the concentration of somatic cells (A), free fatty acids (B), urea (C) and citric acid (D)

Statistical significance between day 0 and day 30 of the experiment $=P \leq 0.05 x, P \leq 0.01 x x, P \leq 0.001 \times x x$ 
Table 5. Milk quality indicators (daily milk production, ECM, FCM) in the individual dairy cows

\begin{tabular}{|c|c|c|c|c|c|c|}
\hline Experimental group & \multicolumn{2}{|c|}{ Milk production $(\mathrm{kg})$} & \multicolumn{2}{|c|}{ ECM } & \multicolumn{2}{|c|}{ FCM } \\
\hline Dairy cows & day 0 & day 30 & day 0 & day 30 & day 0 & day 30 \\
\hline 1 & 2 & 3 & 4 & 5 & 6 & 7 \\
\hline $1_{\mathrm{e}}$ & 28.2 & 30.0 & 33.3 & 33.5 & 33.0 & 31.7 \\
\hline $2_{\mathrm{e}}$ & 24.2 & 25.2 & 26.2 & 28.9 & 24.8 & 28.0 \\
\hline $3_{\mathrm{e}}$ & 24.4 & 24.0 & 25.0 & 27.4 & 23.7 & 26.6 \\
\hline $4_{\mathrm{e}}$ & 30.0 & 28.4 & 31.6 & 32.4 & 29.8 & 30.4 \\
\hline $5_{\mathrm{e}}$ & 31.2 & 39.2 & 31.6 & 40.7 & 30.4 & 39.2 \\
\hline $6_{e}$ & 27.2 & 26.6 & 28.6 & 29.3 & 27.3 & 28.4 \\
\hline 7 e & 26.4 & 27.6 & 25.7 & 30.3 & 24.0 & 28.5 \\
\hline $8_{\mathrm{e}}$ & 26.4 & 26.4 & 27.9 & 29.3 & 26.6 & 28.2 \\
\hline $9_{\mathrm{e}}$ & 30.0 & 30.0 & 36.0 & 34.1 & 35.2 & 33.1 \\
\hline $10_{\mathrm{e}}$ & 25.8 & 28.0 & 29.4 & 31.3 & 28.2 & 29.8 \\
\hline $11_{\mathrm{e}}$ & 27.6 & 29.4 & 29.6 & 30.8 & 28.3 & 29.3 \\
\hline $12_{\mathrm{e}}$ & 26.4 & 26.0 & 26.2 & 26.9 & 24.5 & 25.6 \\
\hline $13_{\mathrm{e}}$ & 28.0 & 26.8 & 29.6 & 30.8 & 28.0 & 29.7 \\
\hline $14_{\mathrm{e}}$ & 28.8 & 26.2 & 34.5 & 35.0 & 33.8 & 34.9 \\
\hline $15_{\mathrm{e}}$ & 26.8 & 25.2 & 33.4 & 32.6 & 32.6 & 32.7 \\
\hline $16_{\mathrm{e}}$ & 25.2 & 27.2 & 24.2 & 32.1 & 22.4 & 31.3 \\
\hline 17 e & 28.8 & 26.8 & 32.1 & 29.0 & 30.7 & 27.7 \\
\hline $18_{\mathrm{e}}$ & 26.2 & 25.2 & 25.4 & 25.8 & 23.5 & 24.0 \\
\hline 19 & 26.8 & 27.2 & 27.7 & 28.9 & 25.9 & 26.9 \\
\hline $20_{\mathrm{e}}$ & 23.4 & 24.8 & 28.0 & 28.7 & 26.0 & 26.3 \\
\hline Average & $27.1 \pm 2.0$ & $27.5 \pm 3.2$ & $29.3 \pm 3.4$ & $30.9 \pm 3.3^{x}$ & $27.9 \pm 3.8$ & $29.6 \pm 3.5 \underline{x}$ \\
\hline Control group & Milk pro & tion $(\mathrm{kg})$ & & & & \\
\hline Dairy cows & day 0 & day 30 & day 0 & day 30 & day 0 & day 30 \\
\hline $1_{c}$ & 38.0 & 38.0 & 43.3 & 43.0 & 40.9 & 40.2 \\
\hline $2_{c}$ & 30.0 & 30.0 & 35.4 & 35.6 & 33.6 & 33.6 \\
\hline $3_{\mathrm{c}}$ & 22.8 & 21.4 & 29.1 & 29.1 & 27.4 & 27.5 \\
\hline $4_{c}$ & 34.0 & 34.0 & 42.1 & 41.0 & 38.7 & 36.6 \\
\hline $5_{\mathrm{c}}$ & 30.0 & 30.0 & 28.5 & 27.9 & 26.2 & 25.5 \\
\hline $6_{c}$ & 23.2 & 20.8 & 28.5 & 24.9 & 26.4 & 24.4 \\
\hline $7_{\mathrm{c}}$ & 22.0 & 21.2 & 23.2 & 22.7 & 22.0 & 21.2 \\
\hline $8_{c}$ & 23.2 & 24.4 & 24.1 & 25.8 & 22.3 & 23.5 \\
\hline $9_{c}$ & 32.0 & 32.0 & 36.5 & 36.3 & 33.2 & 33.2 \\
\hline $10_{c}$ & 22.8 & 24.4 & 25.2 & 30.0 & 23.0 & 28.3 \\
\hline $11_{c}$ & 25.8 & 24.4 & 30.3 & 30.6 & 27.8 & 28.2 \\
\hline $12_{\mathrm{c}}$ & 28.0 & 30.0 & 31.8 & 34.2 & 30.4 & 32.3 \\
\hline
\end{tabular}


Table 3 - contd.

\begin{tabular}{l|ccccccc}
\hline & 1 & 2 & 3 & 4 & 5 & 6 & 7 \\
\hline $13 \mathrm{c}$ & 24.4 & 23.8 & 28.9 & 28.9 & 26.6 & 26.9 \\
$14 \mathrm{c}$ & 14.4 & 15.2 & 15.2 & 17.1 & 14.0 & 16.1 \\
$15 \mathrm{c}$ & 20.4 & 20.8 & 22.3 & 22.8 & 20.3 & 20.8 \\
$16 \mathrm{c}$ & 25.4 & 30.0 & 26.1 & 31.1 & 24.4 & 29.1 \\
$17 \mathrm{c}$ & 30.0 & 30.0 & 31.4 & 31.4 & 29.5 & 29.6 \\
$18 \mathrm{c}$ & 32.0 & 32.0 & 35.9 & 34.7 & 33.2 & 32.0 \\
$19 \mathrm{c}$ & 27.6 & 27.2 & 31.0 & 30.2 & 28.9 & 28.4 \\
$20 \mathrm{c}$ & 26.2 & 25.2 & 27.9 & 28.0 & 26.4 & 26.3 \\
Average & $26.6 \pm 5.4$ & $26.7 \pm 5.5$ & $29.8 \pm 6.7$ & $30.3 \pm 6.2$ & $27.8 \pm 6.3$ & $28.2 \pm 5.6$ \\
\hline
\end{tabular}

Statistical significance between day 0 and day 30 of the experiment $=P \leq 0.05^{\mathrm{x}}$.

Model for ECM and FCM calculation:

ECM $($ Energy corrected milk $)=(0.3246 * \mathrm{~kg}$ milk $)+(12.86 * \mathrm{~kg}$ fat $)+(7.04 * \mathrm{~kg}$ protein)

FCM (Fat corrected milk $-4 \%)=0.4 * \mathrm{~kg}$ milk+15.0* $\mathrm{kg}$ fat (Chen et al., 2008)

\section{Discussion}

In an experiment in which dairy cows (conventional breeding) received three protein concentrates - soybean meal (407 g/day), rapeseed meal $(510 \mathrm{~g} /$ day $)$ and rapeseed cake ( $618 \mathrm{~g} /$ day), milk production efficiency was not affected by the addition of protein feeds and the difference between the groups was 0.8 1/day (Brzóska, 2008). Neither was affected the content of lactose, crude protein and urea in milk. Similar results were observed in our experiment, too. By contrast, the amount of whey significantly increased $(\mathrm{P} \leq 0.01)$ in rapeseed cake as compared with rapeseed meal. The group of dairy cows with the supplement of rapeseed cake exhibited the highest milk fat content, which was, however, without statistical significance. The cows were in the first stage of lactation (Brzóska, 2008). Marston et al. (2011) fed dairy cows in organic farming a standard ration based on maize (control group). The second (experimental) group received additional protein concentrate in the form of pellets. Contents of fats, proteins and lactose remained unchanged in the two groups of animals. The experimental group of dairy cows exhibited significantly increased intake of dry matter, and the authors observed, similarly as we did in our experiment, a higher amount of urea in milk. Similar results were observed in our experiment, too. In our experiment, we recorded a significantly higher milk fat content $(\mathrm{P} \leq 0.05)$, which can be explained by a higher dose of the protein concentrate in our trial. In another experiment, a basic feed ration (maize silage, alfalfa silage, sugar-beet pulp) was supplemented with $10 \%$ of linseed cake. The conclusions indicate that cows fed with the addition of linseed cake exhibited higher milk production. The produced 
milk had lower contents of fat, crude protein and lactose than the control group of dairy cows without the addition of linseed cake (Osięgłowski et al., 2007). After having been fed cotton cake at $0 \%$ (control group), $5 \%, 10 \%$ and $15 \%$, the control group showed the highest daily milk yield of $12.1 \mathrm{~kg} /$ day while the lowest milk yield was recorded in dairy cows with the addition of $15 \%$ of cotton cake $(7.5 \mathrm{~kg} /$ day $)$. Cows in the control group had also the highest amount of milk fat $(\mathrm{P} \leq 0.05)$ as compared with the experimental groups of dairy cows. The experimental group of dairy cows with $15 \%$ of cotton cake in the feeding ration exhibited a significantly higher percentage of crude protein $(\mathrm{P} \leq 0.05)$ as compared with the control group. The content of lactose was identical in all groups (Madzimure et al., 2011). In our experiment, we recorded no increase of milk proteins but rather a significant increase of milk fat content. In an experiment with Holstein cows, a protein concentrate with protected methionine was added into the diet. In cows fed with the addition of methionine, the amount of milk proteins increased $(\mathrm{P} \leq 0.05)$ as compared with dairy cows fed without the addition of this amino acid (Trinacty et al., 2009). In an experiment in which two sources of protein were compared - rapeseed cake and soybean cake (similar components were used also in our experiment), higher production of milk was recorded when feeding rapeseed cakes, but without statistical significance. Both groups showed a significant increase of milk proteins $(\mathrm{P} \leq 0.05)$ as compared with the period before the beginning of the experiment (Shingfield et al., 2003). The addition of soybean protein at 800 $\mathrm{g}$ increased the intake of dry matter in dairy cows, which positively affected milk yield (Faverdin et al., 2003). In our experiment, no difference was found in the production of milk between the control and experimental groups of animals. Since it is not clear from both our and other authors' research whether the addition of protein concentrate affects production efficiency in dairy cows, this fact should be verified in follow-up studies. Goats that were fed with the protected soybean protein, exhibited a significantly higher percentage of milk fat $(3.54 \%, \mathrm{P} \leq 0.001)$ as compared with the control group of animals without the addition of soybean meal (3.14\%). A similar increase was observed in the concentration of urea (which is an indicator of the intake of $\mathrm{N}$-substances) and crude protein in the experimental group $(\mathrm{P} \leq 0.05)$; the results of this trial indicate that the addition of soybean meal can increase the intake of dry matter, too (Chowdhury et al., 2002). A similar increase of milk fat was recorded in our experiment. Mogensen and Kristensen (2002) fed organically farmed dairy cows a standard feeding ration based on maize (control group). The second (experimental) group was fed barley and rapeseed cake. The experimental group exhibited higher percentages of milk proteins and fat by $0.06 \%$ and $0.16 \%$, respectively, without statistical significance. Milk yield and ECM did not significantly differ between the experimental group and the control group either. A similar experiment on Holstein dairy cows was conducted by Mogensen et al. (2004), who added $1 \mathrm{~kg}$ of rapeseed cake to the diet of cows (the same supplement dose was used in our study). The basal ration consisted of clover-grass silage. The addition of rapeseed cake affected neither production efficiency nor the levels of individual milk components. Velik et al. (2008) compared two concentrates in feeding organically farmed dairy cows. The first one was based on corn grains and the second one consisted of horse bean and pea. Milk yield was not affected in either of the two groups. Cows receiv- 
ing the corn concentrate showed a significantly higher percent of milk proteins and a lower amount of urea in milk. In their experiment with feeding soybean, Chen et al. (2008) did not find significant differences in monitoring ECM and FCM between the experimental group and the control group of cows without the soybean supplement in the ration. In both groups, the levels of citric acid were low, likely due to energy deficit. Higher antioxidant potential of milk was measured in an experiment in which $9.8 \%$ of linseed cake was added to the feed ration for dairy cows (Cortes et al., 2012). The addition of linseed cake into the feeding ration of dairy cows at 0,50 , 100,150 or $200 \mathrm{~g} / \mathrm{kg} \mathrm{DM}$ did not result in any difference among the experimental groups of animals during a period of 20 weeks. Monitored parameters were milk production, concentration of proteins, fat, lactose and somatic cells in milk. The amount of unsaturated fatty acids in the milk of dairy cows started to rise already from the dose of $50 \mathrm{~g} / \mathrm{kg}$ DM (Petit and Gagnon, 2011). The results suggest that in spite of the fact that no increase was observed either in the production of milk or in the amount of milk components, the introduction of linseed cake into the feeding ration of dairy cows can improve the health potential of their milk. The increased production of urea indicates a body burden of crude protein with a potential damage to liver and kidneys. In our experiment, the amount of urea in the experimental group of dairy cows averaged $39.2 \mathrm{mg} / 100 \mathrm{ml}$. According to Aguilar et al. (2012), the level of urea in milk above $30 \mathrm{mg} / 100 \mathrm{ml}$ indicates a surplus of crude protein and energy deficiency. An increased level of urea in milk (above $19 \mathrm{mg} / 100 \mathrm{ml}$ ) reduces the percentage of pregnancy by up to $20 \%$ (Butler et al., 1996). According to another study, the increased level of urea in milk (above $30 \mathrm{mg} / 100 \mathrm{ml}$ ) had no negative impact on the reproduction performance of cows (Gath et al., 2012).

In conclusion, our experiment studied the effect of protein concentrate supplement on the qualitative and quantitative composition of milk in organically farmed dairy cows. The measured values show that in the experimental group of dairy cows with the addition of protein concentrate the fat content increased by $7.4 \%(\mathrm{P} \leq 0.05)$, urea increased by $83.1 \%(\mathrm{P} \leq 0.001)$, citric acid increased by $18.6 \%(\mathrm{P} \leq 0.01)$ and free fatty acids decreased by $54.9 \%(\mathrm{P} \leq 0.001)$, ECM decreased by $5.5 \%(\mathrm{P} \leq 0.05)$ and FCM decreased by $6.1 \%(\mathrm{P} \leq 0.05)$. The control group of dairy cows exhibited the content of citric acid in milk increased by $20.0 \%(\mathrm{P} \leq 0.05)$. Other parameters (crude protein, lactose and somatic cells) were not affected. These results demonstrate that a protein concentrate composed of soybean cake, sunflower cake and linseed cake can influence the composition of milk from dairy cows. Nevertheless, a potentially higher health risk has to be taken into account, as indicated by the higher production of urea in milk.

\section{References}

Aguilar M., Hanigan M.D., Tucker H.A., Jones B.L., Garbade S.K., McGil1i a d M.L., S t a $11 \mathrm{ing} \mathrm{s} \mathrm{C.C.,} \mathrm{Kn} \mathrm{ow} 1$ t o n K.F., J a m e s R.E. (2012). Cow and herd variation in milk urea nitrogen concentrations in lactating dairy cattle. J. Dairy Sci., 95: 7261-7268. 
A n o n y m o u s (2010). European Commission Directorate-General for Agriculture and Rural Development. An analysis of the EU organic sector, $80 \mathrm{pp}$.

Brzó s k a F. (2008). Milk production and composition as influenced by soybean meal, rapeseed meal or rapeseed cake in concentrates for dairy cows. Ann. Anim. Sci., 8: 133-143.

Butle r W.R., Ca la man J.J., B e a m S.W. (1996). Plasma and milk urea nitrogen in relation to pregnancy rate in lactating dairy cattle. J. Anim. Sci., 74: 858-865.

Chen P., Ji P., Li S.L. (2008) Effects of feeding extruded soybean, ground canola seed and whole cottonseed on ruminal fermentation, performance and milk fatty acid profile in early lactation dairy cows. Asian-Aust. J. Anim. Sci., 21: 204-213.

Chow d hury S.A., R e x r o th H., K i j or a C., P e t e r s K.J. (2002). Lactation performance of German Fawn goat in relation to feeding level and dietary protein protection. Asian-Aust. J. Anim. Sci., 15: 222-237.

Corte s C., Palin M.F., Gagn on N., B en cha a r C., L a c a s s e P., P e t it H.V. (2012). Mammary gene expression and activity of antioxidant enzymes and concentration of the mammalian lignan enterolactone in milk and plasma of dairy cows fed flax lignans and infused with flax oil in the abomasum. Br. J. Nutr., 108: 1390-1398.

CSN EN ISO 13366-2 (2007). Milk - determination of somatic cells (in Czech). Praha, 36 pp.

CSN ISO 2446 (2010). Milk - determination of fat content (in Czech). Praha, 16 pp.

CSN 570530 (1974). Methods for testing of milk and liquid dairy products (in Czech). Praha, 108 pp.

D an es M.A.C., Chag a s L.J., P e d ros o A.M., S a n to s F.A.P. (2013). Effect of protein supplementation on milk production and metabolism of dairy cows grazing tropical grass. J. Dairy Sci., 96: 407-419.

Faverdin P., M'Hamed D., Verite R. (2003). Effects of metabolizable protein on intake and milk production of dairy cows independent of effects on ruminal digestion. Anim. Sci., 76: $137-146$.

Gath V.P., Crow e M.A., O'Callaghan D., B ol and M.P., Duffy P., Lonergan P., Mul $1 \mathrm{ig}$ a n F.J. (2012). Effects of diet type on establishment of pregnancy and embryo development in beef heifers. Anim. Reprod. Sci., 133: 139-145.

H o molka P., K u d r n a P. (2006). Replacement of animal feed for ruminants (in Czech). Výzkumný ústav živočišné výroby. Praha - Uhř́něves, Czech Republic, 62 pp.

Hoshide A.K., Halloran J.M., Kersbergen R.J., Griffin T.S., DeFauw S.L., L a G a s s e B.J., J a in S. (2011). Effects of stored feed cropping systems and farm size on the profitability of Maine organic dairy farm simulations. J. Dairy Sci., 94: 5710-5723.

L e 1 y o n B., C hat e 11 i e r V., D a n i e 1 K. (2012). Production strategies after the end of milk quotas: an analysis based on bio-economic modeling. INRA Prod. Anim., 25: 67-76.

Madzimure J., Musimurimwa C., Chivandi E., Gwiriri L., Mamhare E. (2011). Milk yield and quality in Guernsey cows fed cottonseed cake-based diets partially substituted with baobab (Adansonia digitata L.) seed cake. Trop. Anim. Health Prod., 43: 77-82.

Marst on S.P., C lark G.W., A n d e r s on G.W. (2011). Maximizing profit on New England organic dairy farms: An economic comparison of 4 total mixed rations for organic Holsteins and Jerseys. J. Dairy Sci., 94: 3184-3201.

Mogensen L., Kristensen T. (2002). Effect of barley or rape seed cake as supplement to silage for high-yielding organic dairy cows. Acta Agricult. Scand. Section A - Anim. Sci., 52: $243-252$.

Mog en s e n L., Ing vart s e n K.L., K r is ten s en T., S e e s te d S., T h a m s b org S.M. (2004). Organic dairy production based on rapeseed, rapeseed cake or cereals as supplement to silage ad libitum. Acta Agricult. Scand. Section A - Anim. Sci., 54: 81-93.

O s i ęg łow s ki S., S trze te ls ki J.A., Z y m on M., K o w a l c z y k J. (2007). Effect of fish oil and high or low linolenic acid linseed or rapeseed on fatty acid composition of cow's milk. Ann. Anim. Sci., 7: 63-74.

P e tit H.V., Gagn on N. (2011). Production performance and milk composition of dairy cows fed different concentrations of flax hulls. Anim. Feed. Sci. Technol., 169: 46-52.

Shingfield K.J., Vanhatalo A., Huhtanen P. (2003). Comparison of heat-treated rapeseed expeller and solvent-extracted soya-bean meal as protein supplements for dairy cows given grass silage-based diets. Anim. Sci., 77: 305-317. 
Tetens J., Seidenspinner T., Buttchereit N., Thaller G. (2013). Whole-genome association study for energy balance and fat/protein ratio in German Holstein bull dams. Anim. Genet., 44: 1-8.

Trinacty J., Krizova L., Richter M., Cerny V., Riha J. (2009). Effect of rumen-protected methionine, lysine or both on milk production and plasma amino acids of high-yielding dairy cows. Czech J. Anim. Sci., 54: 239-248.

Velik M., S te inw i d d e r A., Kn a u s W.F. (2008). Lupin-pea cereal mixture or cereals as supplements for organic dairy cows. Biol. Agric. Hortic., 25: 339-351.

Will e r H., K i l c h e r L. (2009). Editors. The World of Organic Agriculture - Statistics and Emerging Trends 2009. IFOAM, Bonn, FiBL, Frick, 304 pp.

Zem a n L., Dolezal P., Kopriva A., Mrkvicova E., Prochazkova J., Ryant P., Sklad a nka J., Strakova E., Suchy P., Vesely P., Z el enka J. (2006). Nutrition and feeding of livestock (in Czech). Praha, Czech Republic, Profi Press, 360 pp.

Zeman L., Simecek K., Krasa A., Simek M., Lossman J., Trinacty J., Rudolfova S., Vesely P., Hap I., Dolezal P., Kracmar S., Tvrznik P., Michele P., Ze manova D., Siske V. (1995). Feedstuffs (in Czech). Pohořelice, Czech Republic, SPRINT Znojmo, 465 pp.

Received: 7 V 2013

Accepted: 31 X 2013 